\title{
The Rotifer fauna of Guatemala and Belize: survey and biogeographical affinities
}

\author{
Alma Estrella García-Morales \& Manuel Elías-Gutiérrez \\ El Colegio de la Frontera Sur. Av. Centenario km 5.5 Chetumal 77900, Quintana Roo, México; eliasgm@ecosur-qroo.mx
}

\author{
Received 11-XII-2001. Corrected 30-VIII-2006. Accepted 15-XII-2006.
}

\begin{abstract}
Rotifer samples were obtained from 29 localities in northern Guatemala and central-southern Belize during March 2000 and June 2001. A total of 119 species were identified. Ten selected taxa are illustrated and commented: Euchlanis semicarinata, Lepadella apsicora, L. cryphaea, Lecane curvicornis f. lofuana, L. whitfordi, Monommata maculata, Scaridium bostjani, Trichocerca elongata f. braziliensis, and $T$. hollaerti. The species Lepadella rhomboidula is a first record for the American Continent. The species are $71 \%$ cosmopolitan, $6 \%$ tropicopolitan, and $4.2 \%$ restricted to the subtropics. The Guatemala species number range was Petén-Itza lake (53 taxa), and Raxruja pool (three). La Democracia pool (49 taxa), and the Blue Hole sink-hole (six species) were the extremes in Belize. In total, 68 of the recorded taxa are new for Guatemala and 91 for Belize. Additionally, 47 species are registered by the first time in Central America. A comparison between these two countries and Mexico revealed that the south part of the latter conform a cluster with them, emphasizing the transitional character of this region between the Nearctics and the Neotropics. Furthermore, Guatemala and Belize have differences in species assemblages, as a response to the nature of their particular environments and topographical accidents. Rev. Biol. Trop. 55 (2): 569-584. Epub 2007 June, 29.
\end{abstract}

Key words: rotifera, taxonomy, diversity, distribution, Guatemala, Belize.

In Central America, studies on taxonomy and distribution of rotifers are relatively scarce and old (ie. Collado et al. 1984). Currently, knowledge on the rotifer fauna of Guatemala is poor compared with North and South America (Koste and De Paggi 1982, De Paggi and Koste 1995, Segers 1997, Sarma 1999, Sarma and Elías-Gutiérrez 1999a, b, García-Morales and Elías-Gutiérrez 2004). On the other hand, Belize's fauna is completely unknown; there are no previous reports on the rotifers from this country. Lately, a preliminary study on Cladoceran fauna published by Elías-Gutiérrez et al. (2006), emphasized about the diverse aquatic systems found in this region, and the effect on their fauna. In case of rotifers, recent publications are limited to the Mexican side, close to both countries. García-Morales and
Elías-Gutiérrez (2004) recorded 128 species from 36 localities in the south of Mexico. A previous study by Sarma and Elías-Gutiérrez (1999a) in 12 localities from Yucatan rendered 102 species. In both papers, a total of 37 new records for the region were figured, majority of them regarded as warm-stenotherm (GarcíaMorales and Elías-Gutiérrez 2004).

North of Guatemala and Belize possess highly contrasting environments due to topographic accidents, quite different with the homogeneous adjacent south of Yucatan Peninsula. Nevertheless, all of them belong to the same biotic province, named CampechanoPetenense (UNAM 1990). As a result of the presence of mountain systems (for example Mayan mountains in Belize and Sierra Chinajá in north of Guatemala) and other topographic 
accidents, both countries have diverse microhabitats reflected in the vegetation and aquatic systems. As a result, in the case of fish fauna for example, 13 endemic species dwell in north of Guatemala (Valdéz-Moreno et al. 2005). Many of the aquatic systems from these regions still remain as pristine and non polluted environments (Valdéz-Moreno et al. 2005, pers. obs.).

The aims of this study were to provide data on the species of the rotifer fauna found in zooplankton collections gathered in several freshwater bodies from Guatemala and Belize, to include a comment about the distribution of these animals in both countries, and to compare the species assemblage with adjacent Mexico.

\section{MATERIALS AND METHODS}

Rotifers were qualitatively collected using standard plankton net; $50 \mu \mathrm{m}$ mesh size, attached to a handle in the littoral zone. Horizontal and vertical tows, with the same kind of net were performed, when a limnetic zone (more than $5 \mathrm{~m}$ deep) was clearly defined in the surveyed water body. As a minimum, 2001 of water were filtered for each sample. After collections, material was preserved in $4 \%$ formalin. At least five samples represented bigger systems, as Petén Lake, and the small puddles were characterized by one. Littoral sampling included all possible habitats for rotifers: submersed vegetation, bottom dwellers, etc. Temperature, depth, and Secchi transparency were measured at every site to give a reference about the environment where the rotifers dwell. In total, 11 localities were sampled in Guatemala and 18 from Belize (Fig. 1). Each place was visited once. Data on physical parameters and geographical coordinates of the studied sites are presented in Table 1. In general, the surveyed systems are shallow (0.2-1.5 m depth), except for Petén-Itza Lake, the largest system. Transparency showed values ranging between $0.17-2 \mathrm{~m}$, whereas temperature had values between $23-37^{\circ} \mathrm{C}$, ranges also found in other surveys from the region (Sarma and Elías-Gutiérrez 1999a, García-Morales and Elías-Gutiérrez 2004). Date of collection, geographical coordinates, and environmental data of each sampling site are resumed in Table 1. Animals were sorted with a stereomicroscope and identified using a compound microscope. Identification of rotifers was made following Koste 1978, Nogrady et al. 1995, Segers 1995, De Smet and Pourriot 1997, Nogrady and Segers 2004. Also we consulted the Academy of Natural Sciences of Philadelphia database on rotifers (Jersabek et al. 2003). When needed, animals were dissolved in a sodium hypoclorite solution to allow examination of trophi. Information about varieties and forms is provided because rotifer taxonomy is still under discussion. For example, former varieties have been recently proposed to be good species (ie. Sarma and Nandini 2002 proposed to consider macracanthus, a former variety of Brachionus patulus, as a different species). Selected new records in Central America were illustrated by using a camera lucida. All material and original samples are deposited at the reference

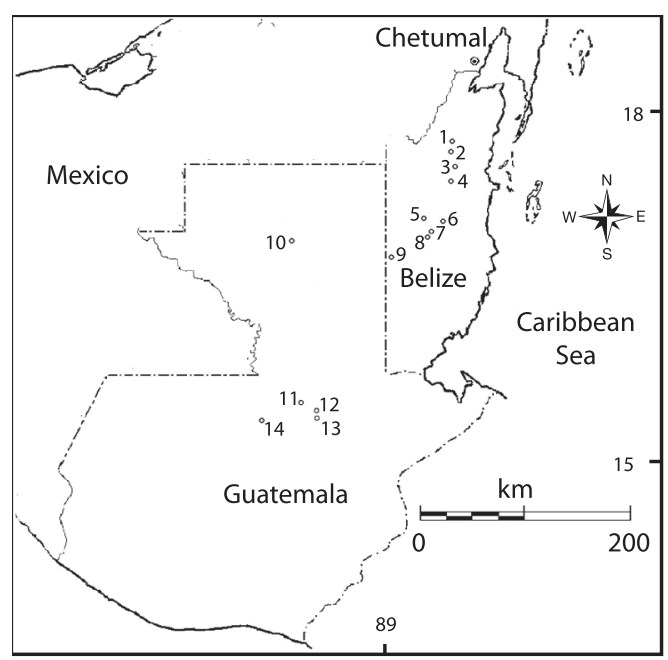

Fig. 1. Guatemala and Belize with localities collected (some of them were grouped due to their proximity). 1. Charco Seco; 2. Laguna and Estanque Crooked Tree; 3. Sand Hill; 4. La Democracia and Dos Charcos; 5. Charco Dos Puentes and Spanish Lockout I-III; 6. Blue Hole and Caves Branch; 7. Pine Ridge I-III; 8. Río on Pools and Río Puente Largo; 9. Caracol; 10. Petén-Itza Lake; 11. Charco El Pato and Sayaxché; 12. Charco Raxruja, Río Candelaria, Charco Rayulia and Río San Simón; 13. Charco Sebol and Río Sebol; 14. Río Chajmaic and Río Dolores. 
TABLE 1

Physical variables and location of the water bodies sampled

Place

\section{GUATEMALA}

A Laguna Petén-Itza

B Sayaxché

C Charco Raxruja

D Río Candelaria

E Charco Sebol

F Río Sebol

G Charco Río Chajmaic

H Río Dolores

I Charco Rayulia

J Río San Simón

K Charco del Pato

\section{BELIZE}

L Charco Seco

M Charco Dos Puentes

N Spanish Lokcout I

Ñ Spanish Lokcout II

O Spanish Lokcout III

P Pine Ridge I

Q Pine Ridge II

R Pine Ridge III

S Caracol

T Laguna Crooked Tree

U Estanque Crooked Tree

V Blue Hole

W Rio on Pools

$\mathrm{X}$ Río Puente Largo

Y La Democracia

Z Sand Hill

AA Dos Charcos

AB Caves Branch
Geographical coordinates

Latitude N Longitude W

$\begin{array}{cc}16^{\circ} 55^{\prime} 44^{\prime \prime} & 89^{\circ} 53^{\prime} 38^{\prime \prime} \\ 16^{\circ} 12^{\prime} 33.6^{\prime} & 90^{\circ} 10^{\prime} 47.3^{\prime \prime} \\ 15^{\circ} 53^{\prime} 29^{\prime \prime} & 90^{\circ} 05^{\prime} 51^{\prime \prime} \\ 15^{\circ} 53^{\prime} 04^{\prime \prime} & 90^{\circ} 11^{\prime} 12^{\prime \prime} \\ 15^{\circ} 40^{\prime} 25^{\prime \prime} & 89^{\circ} 56^{\prime} 39^{\prime \prime} \\ 15^{\circ} 40^{\prime} 25^{\prime \prime} & 89^{\circ} 56^{\prime} 39^{\prime \prime} \\ 15^{\circ} 43^{\prime} 15^{\prime \prime} & 89^{\circ} 56^{\prime} 24^{\prime \prime} \\ 15^{\circ} 44^{\prime} 17^{\prime \prime} & 90^{\circ} 22^{\prime} 34^{\prime \prime} \\ 15^{\circ} 54^{\prime} 41^{\prime \prime} & 90^{\circ} 06^{\prime} 06^{\prime \prime} \\ 15^{\circ} 50^{\prime} 39^{\prime \prime} & 90^{\circ} 17^{\prime} 01^{\prime \prime} \\ 16^{\circ} 07^{\prime} 36^{\prime \prime} & 90^{\circ} 10^{\prime} 53^{\prime \prime}\end{array}$

Number$$
\text { Colle }
$$$$
\text { date }
$$

Temperature

Maximum Secchi of samples date $\quad\left({ }^{\circ} \mathrm{C}\right) \quad$ depth $(\mathrm{m}) \quad \operatorname{disk}(\mathrm{m})$

\section{$17^{\circ} 55^{\prime} 31.5^{\prime \prime}$}

$88^{\circ} 31^{\prime} 10^{\prime \prime}$

17¹3'27.6” 88०52'29.2”

$17^{\circ} 13^{\prime} 54.1^{\prime \prime}$

$88^{\circ} 55^{\prime} 49.2$ "

17²13'59.4"'

$88^{\circ} 56^{\prime} 04.4^{\prime \prime}$

$17^{\circ} 14^{\prime} 17.1^{\prime \prime}$

$88^{\circ} 56^{\prime} 49.3$ "

$17^{\circ} 02^{\prime} 55.6^{\prime \prime}$

$88^{\circ} 56^{\prime} 57.8^{\prime \prime}$

1703'04.9"

$88^{\circ} 57^{\prime} 17.5^{\prime \prime}$

$17^{\circ} 02^{\prime} 56.1^{\prime \prime}$

88०57'03.1"

164'34.1"

$89^{\circ} 07^{\prime} 13.7$ '

1746’30.4” 88०31'51.5"

1746'24.7'"

1709'26.6”'

$88^{\circ} 30^{\prime} 54.8^{\prime \prime}$

1659'16.6"

$88^{\circ} 41^{\prime} 00.6^{\prime \prime}$

16 51 '52.6"

$17^{\circ} 21 ' 53.9^{\prime \prime}$

17³5'41.5”,

$17^{\circ} 21^{\prime} 53$.

$17^{\circ} 08^{\prime} 53.2^{\prime \prime}$

$\begin{array}{ll}21 / 03 / 00 & 30 \\ 18 / 05 / 01 & 32 \\ 27 / 03 / 00 & 29 \\ 27 / 03 / 00 & 28 \\ 23 / 03 / 00 & 26 \\ 22 / 03 / 00 & \text { ND } \\ 23 / 03 / 00 & 23 \\ 26 / 03 / 00 & 26 \\ 27 / 03 / 00 & 29 \\ 25 / 03 / 00 & 25 \\ 27 / 03 / 00 & 29\end{array}$

$\begin{array}{cc}40 & 2 \\ 1 & 0.25 \\ 0.39 & 0.39 \\ 0.5 & 0.5 \\ 0.8 & 0.8 \\ 1 & 1 \\ 0.4 & 0.4 \\ 0.5 & 0.5 \\ 1.17 & 1.17 \\ 0.25 & 0.25 \\ 0.79 & 0.47\end{array}$

\section{$14 / 06 / 01 \quad 36$}

0.2

14/06/01

34

1.5

14/06/01

36

0.2

$14 / 06 / 01 \quad 35$

0.55

14/06/01

$$
37
$$

$$
0.2
$$

15/06/01

25.5

0.56

0.33

0.4

0.5

0.7

0.73

0.56

$16 / 06 / 01 \quad 29$

$16 / 06 / 01$

0.67

0.67

collection located in El Colegio de la Frontera Sur, Chetumal Unit.

To compare the fauna between Belize and Guatemala as well as Mexico, we performed a cluster analyses with the Sorensen Index (pres-

ence/absence) (Legendre and Legendre 2000) between all localities with known rotifer fauna. In the case of Mexico, we used already published data by Silva-Briano and Segers (1992), RicoMartínez and Silva-Briano (1993), Kutikova 
and Silva-Briano (1994), Sarma et al. (1996, 2000), Sarma and Elías-Gutiérrez (1997, 1998, 1999a, b, 2000), Silva-Briano and AdabacheOrtíz (1999), Rico-Martínez et al. (2003) and García-Morales and Elías-Gutiérrez (2004). Due to the fact that Mexico has a bigger size with a complex topography, the records of rotifer fauna were grouped as Central Plateau, Pacific slope, North, Southeast and Yucatan Peninsula regions.

\section{RESULTS}

A total of 119 species were recorded (Table 2); 68 are new records to Guatemala, and 91 taxa are recorded by the first time in Belize. The species found belong to two orders, 20 families, 35 genera and eight forms. The highest number of species was contained in Lecane, with 37 species (31\%), Trichocerca 14 $(11.8 \%)$, and Lepadella with 11 taxa $(9.32 \%)$. These results agree in part with other reports from tropical zones, where Lecane is the most common genus, followed by Lepadella (Segers et al. 1998, Sarma and Elías-Gutiérrez 1999a).

In the following section, a short description of selected taxa considered as new records for Central America is provided. Distributional data follow De Ridder and Segers 1992, unless otherwise stated.

Euchlanis semicarinata Segers, 1993 (Fig. 2): With a characteristic shallow dorsal keel. Dorsal and ventral plates present. Nearly circular in transversal view. Known from Nigeria, French Guyana, and Bolivia (Pourriot 1996, Segers et al. 1998).

Lepadella apsicora Myers, 1934 (Fig. 3a, b): Body ovoid, with a characteristic "V"shaped sinus. Distal segment of foot longer than proximal. Toes asymmetric. Known from USA and Ecuador (Myers 1934, Koste and Shiel 1989, Jersabek et al. 2003).

Lepadella cryphaea Harring, 1916 (Fig. 4a, b): Related with L. acuminata. Lorica ovoid, posterior dorsal plate pointed. Characterized by the presence of folds and one dorsal-median keel. Known from Canada, USA, Brazil and possibly Europe (Koste 1978, Segers and Sarma 1993, Jersabek et al. 2003).

Lepadella rhomboidula (Bryce, 1890) (Fig. 5): Known by some as L. triptera $f$. rhomboidula (see Koste 1978). In general view, body rhomboid. With a median keel on dorsal plate. Ventral margin of head "U"-like. Europe, India, Indonesia, and New Zealand. This is the first record of this species in the Americas, it was found only in one locality from Belize Mayan Mountains.

Lecane curvicornis $f$. lofuana (Murray, 1913) (Fig. 6a, b): Ventral plate broader than dorsal, two antero-lateral spines. Dorsal and ventral margins slightly convex. Posterior end of lorica trilobate. The species is relatively common, with cosmopolitan distribution (Segers 1995), but the $f$. lofuana has been reported more rarely, basically from Singapore and Brazil.

Lecane whitfordi (Ahlstrom, 1938) (Fig. 7a, b): Related with L. obtusa. Dorsal plate broader than ventral, head aperture margins straight or slightly convex. Antero-lateral corners with long triangular spines. Foot simple with a toe ending in two separated claws. Known only from two localities in North Carolina (USA), Lake Waccamaw, the type locality (Segers 1995), and Lake Mattamuskeet (Jersabek et al. 2003). Possibly a record of $L$. obtusa by Paggi (1989) could be L. whitfordi, according to Segers (1995). It was found only in one locality from Belize.

Monommata maculata Harring and Myers, 1924 (Fig. 8a, b): Body slender. Foot with two segments, toes unequal in length. Mastax with fulcrum conical, short; rami with complex dentition. Unci with three long teeth. Manubrium curved, with lamella. A common species with cosmopolitan distribution (Nogrady et al. 1995).

Scaridium botsjani Dames and Dumont, 1974 (Fig. 9): Trunk broad. Second segment of foot long. Toes relatively long. Fulcrum with a median-ventral crest. Basal plate well developed. Rami with long teeth. Manubria relatively narrow, with rounded alulae. Nepal is the type locality, but it is considered a warm stenoterm in all tropics (Segers 1995). 


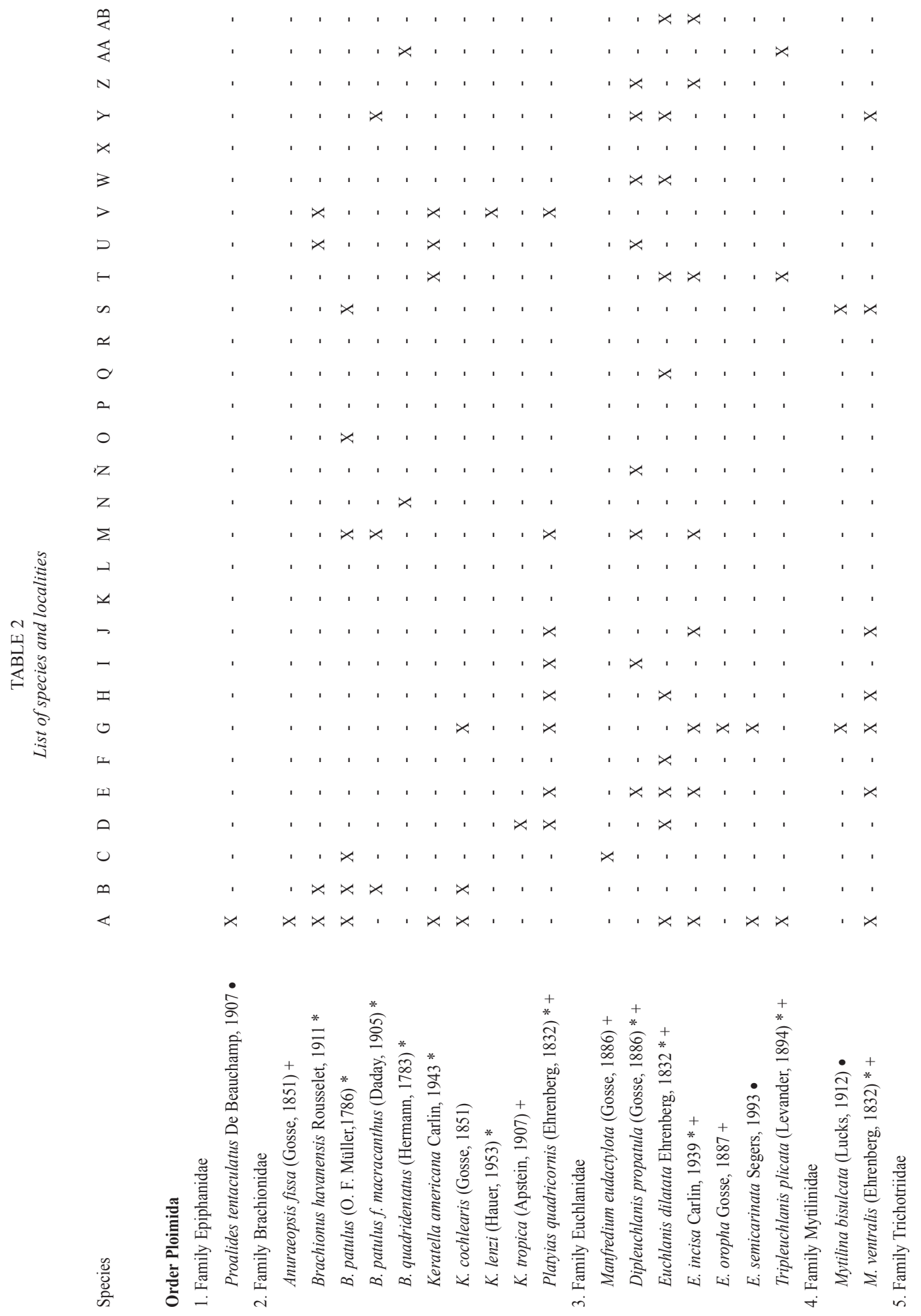




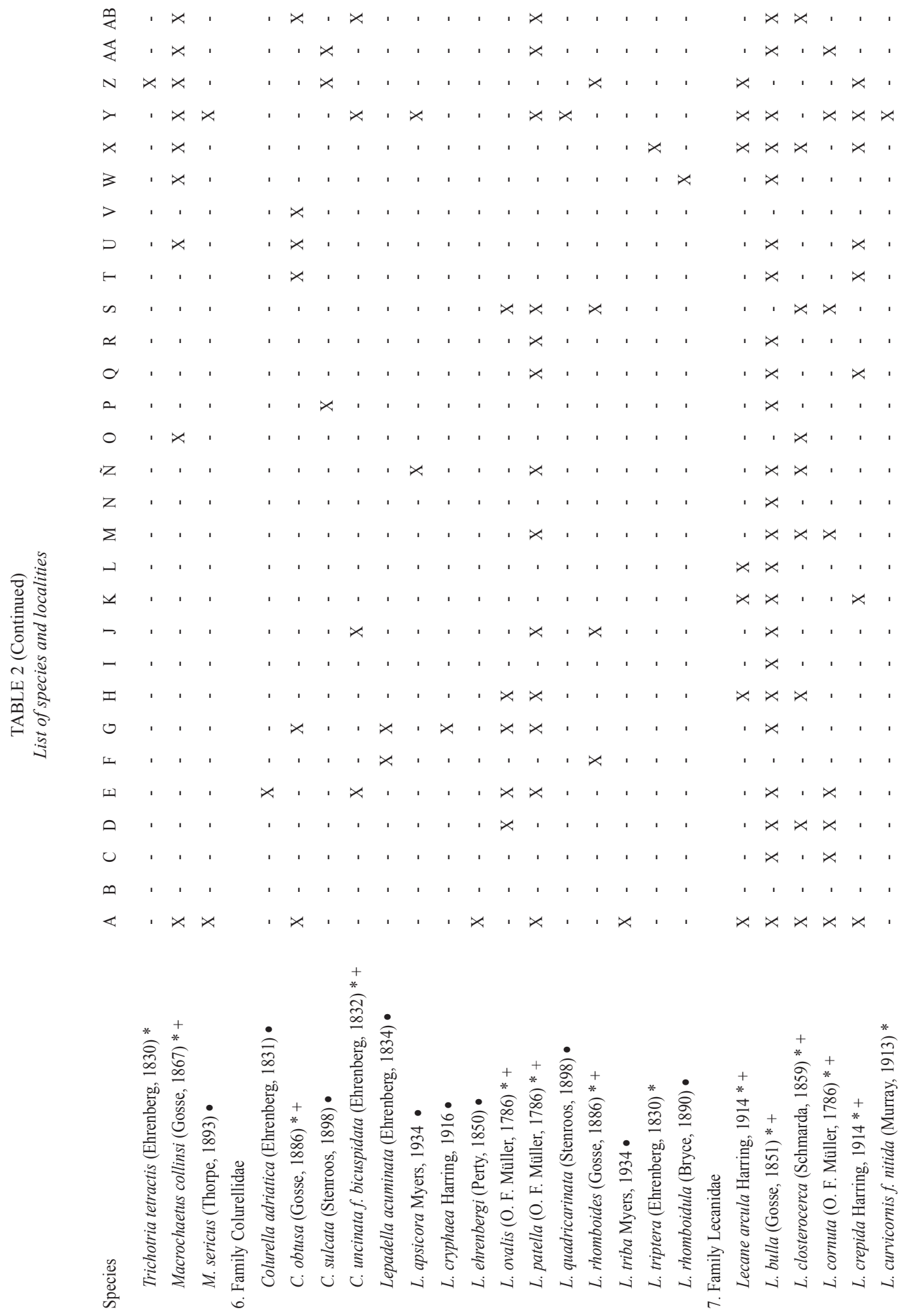



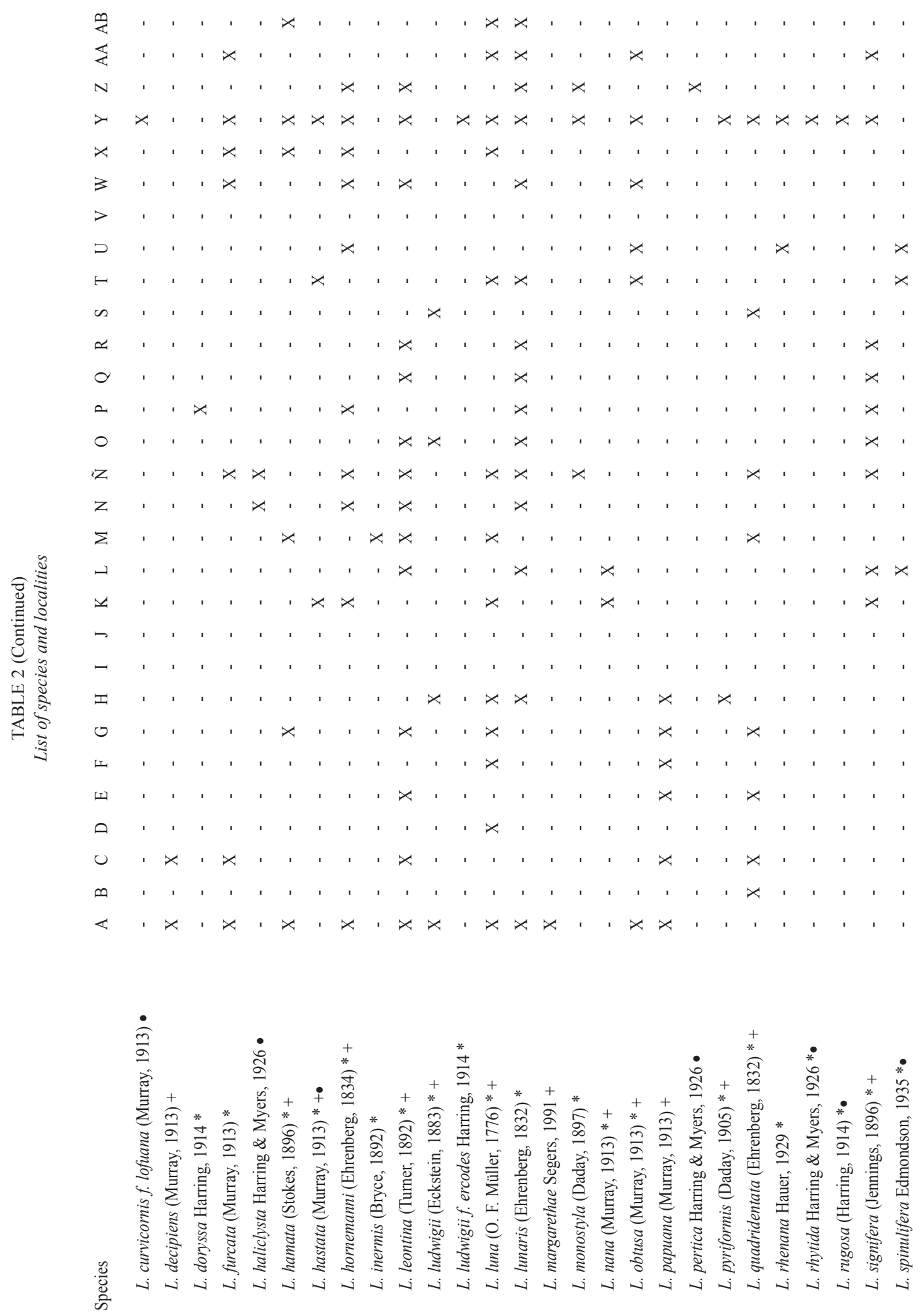


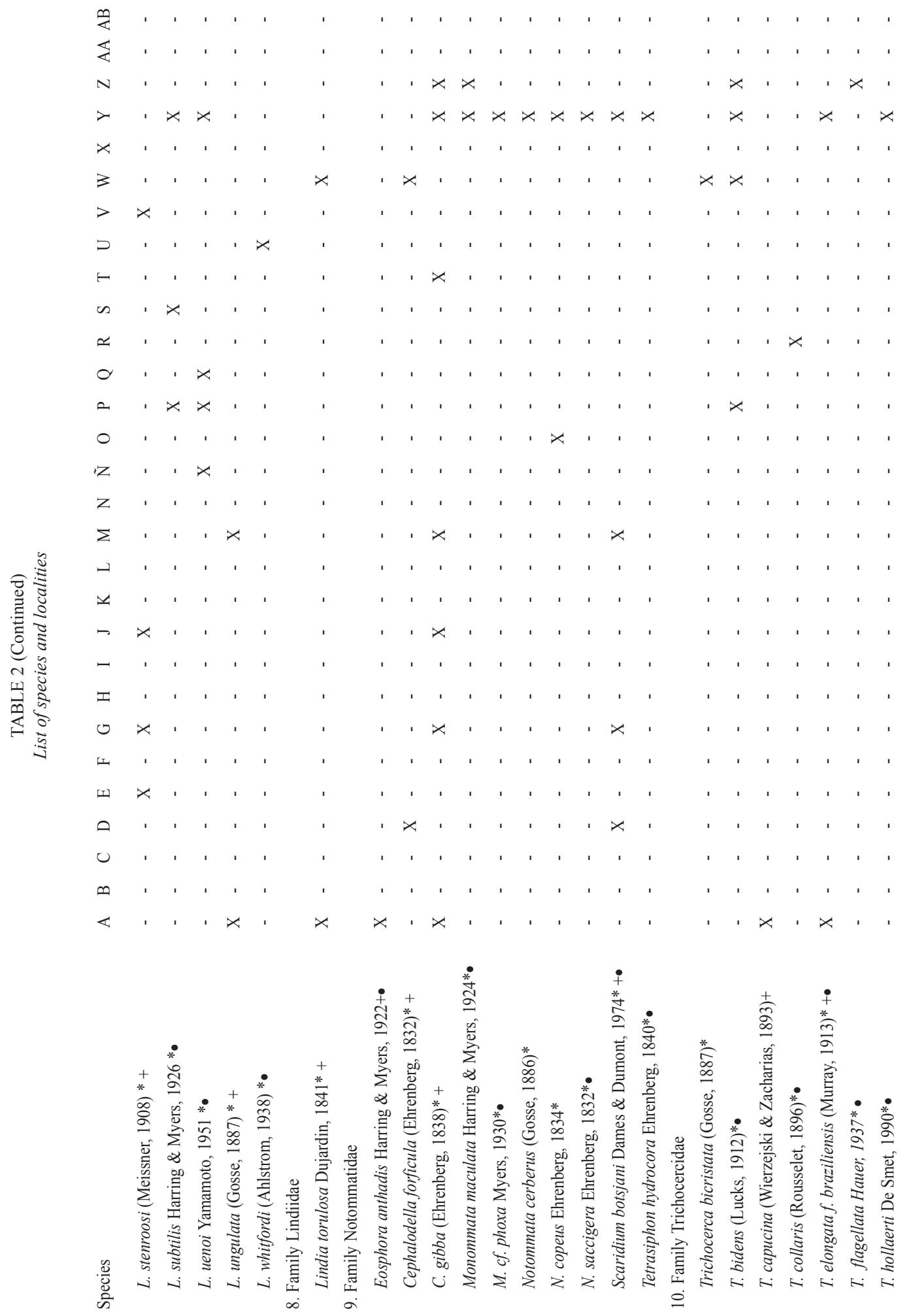



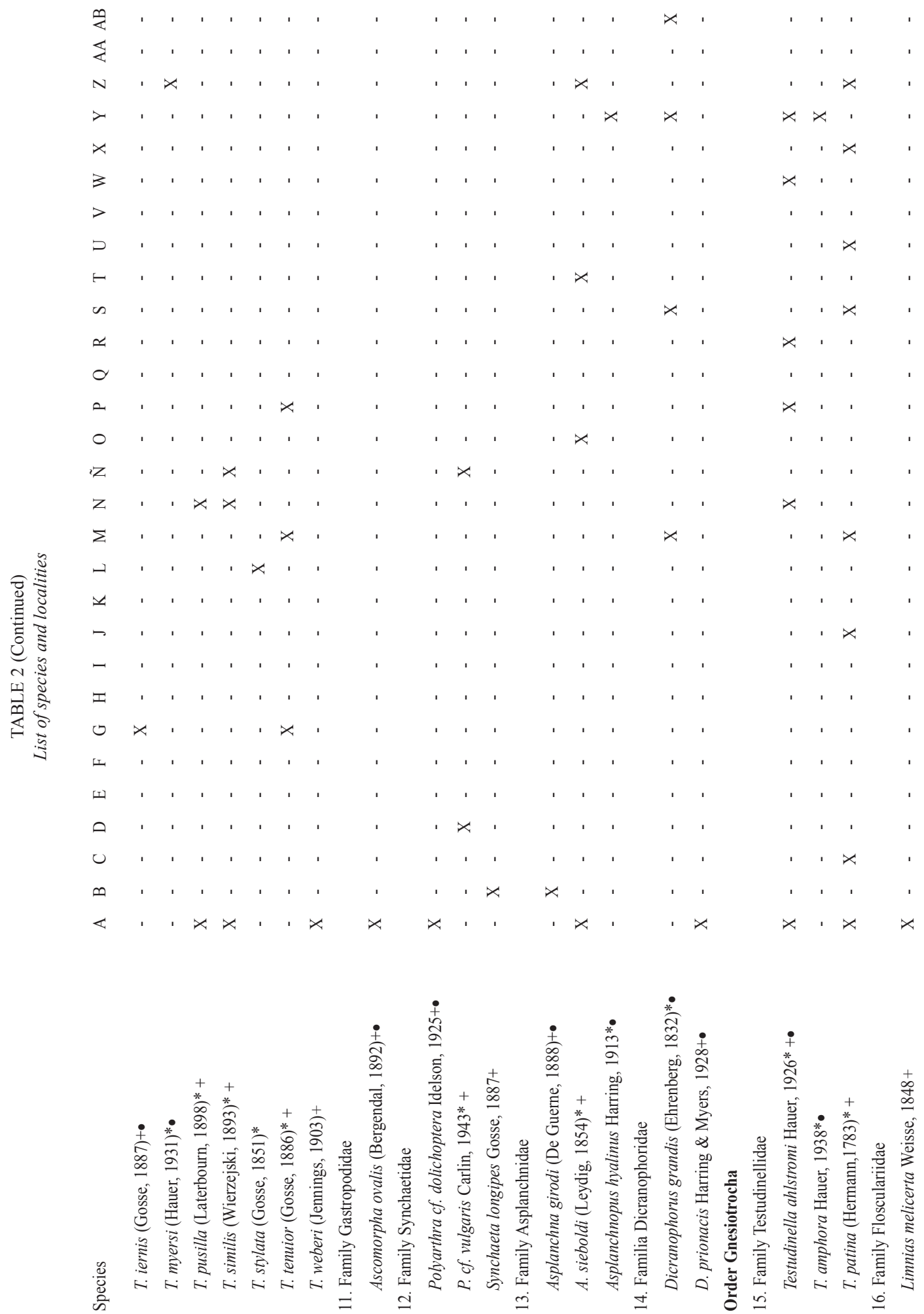
Trichocerca elongata braziliensis (Murray, 1913) (Fig. 10): Body cylindrical. Anterior margin smooth, double dorsal keel. Medial part of body broadest. With one long toe, and with small substilis in both sides. Trophi asymmetric; left manubria hook-shaped. Left uncus longer. Known from Malaysia, Singapore, and South America.

Trichocerca hollaerti De Smet, 1990 (Fig. 11): Dorsal keel covers all body. Head aperture margins with longitudinal folds. Right toe elongated, the left one "S"-like. It has been reported in Africa, and Brazil (Segers and Sarma 1993).

\section{DISCUSSION}

In total 47 taxa are new to the entire Central America region (Collado et al. 1984, De Ridder and Segers 1992). Most of these species are known in southern Mexico (Sarma 1999, García-Morales and Elías-Gutiérrez 2004).

Some species of Euchlanis, Cephalodella, Scaridium and Sinantherina could not be identified due to taxonomic problems or by their poor preservation. Some unidentified bdelloids were also present. These doubtful taxa were not included in the list.

As recorded herein, the fauna from Guatemala and Belize represents the first contemporaneous addition since Collado et al. (1984). Thus, the number of new records in the list is not surprising. Guatemala and Belize are small countries in size, but they possess complex and varied environments as highlands and lowlands with rainforest, floodplains, mangroves, savanna, Pinus forest, etc. (Archibold 1995). In particular, the region of Pine Ridge, located in the Mayan mountains, has a dramatic change from tropical vegetation to a Pinus forest in just few meters, possibly as a result of changes in the soil composition and altitude (Elías-Gutiérrez et al. 2006). Here we found the lower temperatures of water and several unique records, as L. rhomboidula.

For comparison, small countries such as Ecuador and Bolivia have reports of ca. 300 and 153 species recorded in their freshwater 

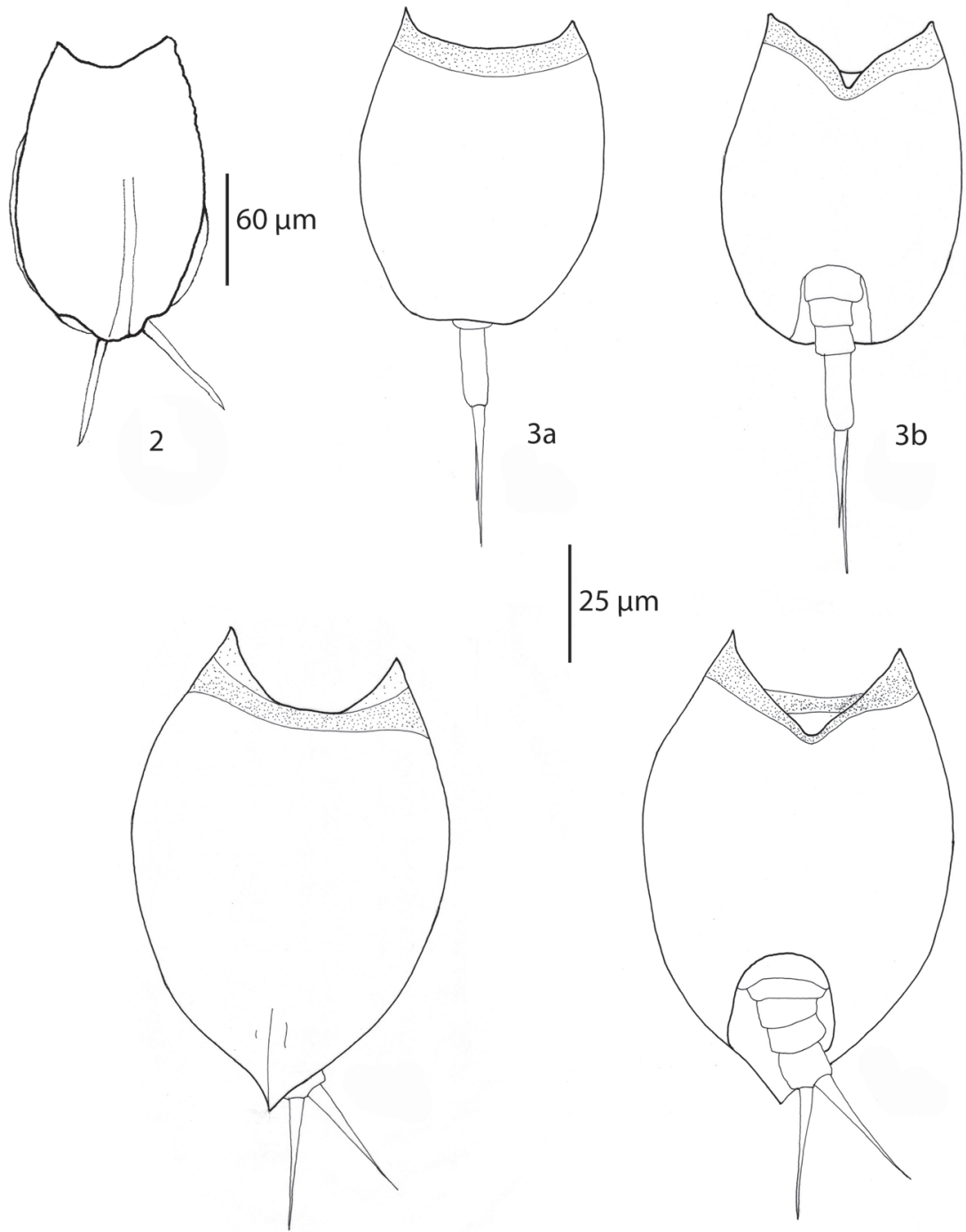

$4 a$

$4 b$

Fig. 2. E. semicarinata (dorsal). Fig. 3A. L. apsicora (dorsal), B. Ventral. Fig. 4A. L. cryphaea (dorsal), B. Ventral.

systems, respectively (Koste and Böttger 1992, Segers et al. 1998).

Out of the 119 taxa reported here, up to $70 \%$ are cosmopolitan, about $6 \%$ are tropicopolitans, $4.2 \%$ are subtropical and $6.7 \%$ have limited distribution to one locality. Two taxa $(1.7 \%)$ are neotropical: Brachionus havanaensis and Hexarthra intermedia f. braziliensis. The present study demonstrated the occurrence of some rotifers recorded earlier from Africa, Asia, Europe, New Zealand, USA, and South America (De Ridder and Segers 1992). For example this is the first time that L. rhomboidula is reported in the Americas.

Systems with highest and lowest diversity in Guatemala were Petén-Itza and Raxruja with 53 and 3 species, respectively. In Belize, the localities La Democracia and Blue Hole had 

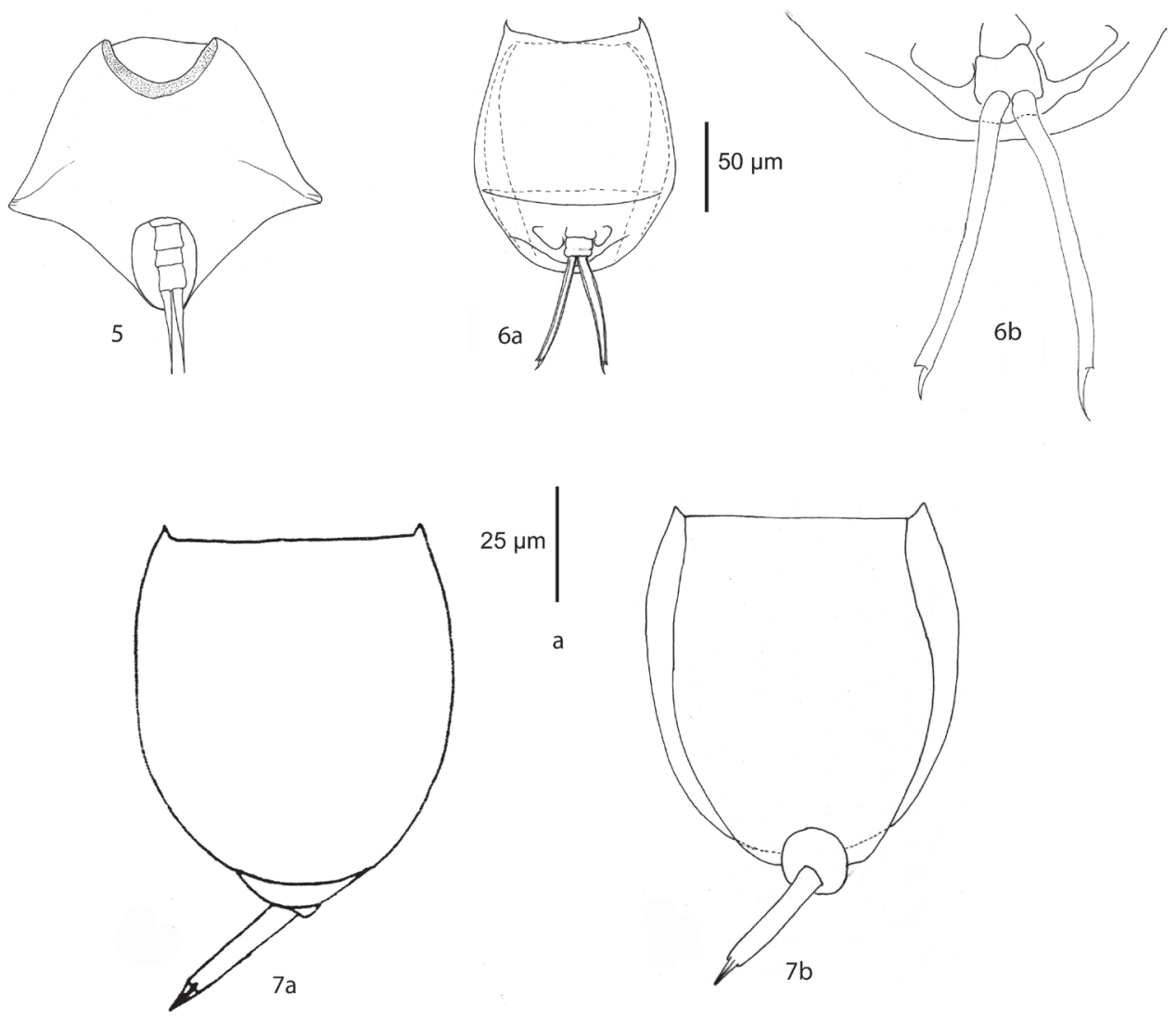

Fig. 5. L. rhomboidula (ventral). Fig. 6A. L. curvicornis f. lofuana (ventral), B. Close view of foot. Fig. 7A. L. whitfordi (dorsal), B. Ventral.
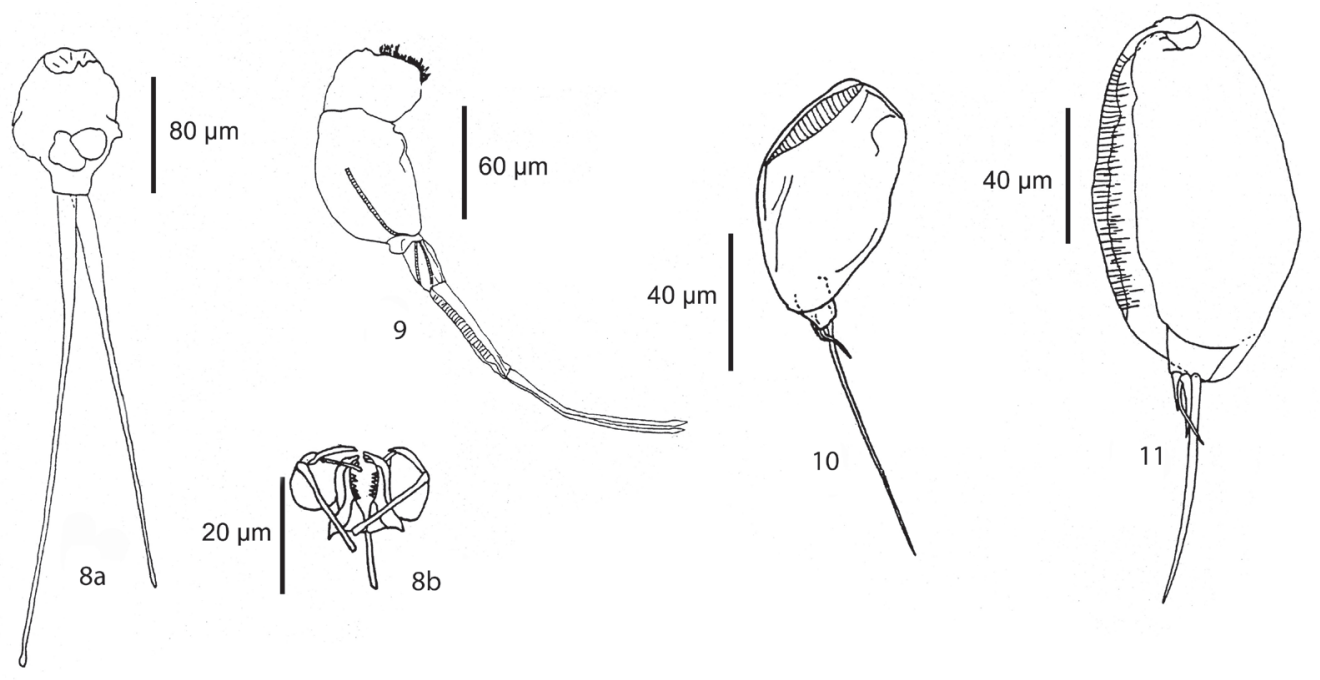

Fig. 8. A. M. maculata (habitus ventral), B. trophi (ventral). Fig. 9. S. bostjani (lateral). Fig. 10. T. elongata f. braziliensis (lateral). Fig. 11. T. hollaerti (ventral). 
49 and 6 taxa, respectively. These numbers are low, when compared with other neotropical systems. For example Segers et al. (1998) found 104 species of rotifers in only three samples from Laguna Bufeos, Bolivia and Sarma and Elías-Gutiérrez (1998) found 78 species in a Mexican pond. The majority of the species recorded in both, Petén-Itza and La Democracia, were present in littoral samples collected from submerged vegetation, which harbors a high diversity (Uicab-Sabido 2001). It should be noticed that all samples from Petén-Itza Lake were taken in the west side, near the Flores Island and San Benito town, the most affected region by human pollution. The east shore, less affected, was not sampled in this survey.

Knowledge on the rotifer fauna of Central America is still limited when compared with that of North and South America. Presently, Panama is the country with the highest number of species recorded (180 taxa) in the region (De Ridder and Segers 1992). Since the early report by Harring 1914, who recorded 109 species, 71 taxa have been added (Koste and De Paggi 1982, Collado et al. 1984). With this study the number of species of Guatemala and Belize increased, but remains still behind that of Panama. The necessity of systematic research on rotifers is urgent in the rest of Central American countries. For example, in Nicaragua there are recorded 52 species only, Costa Rica 41, Honduras 24, and El Salvador 13 (De Ridder and Segers 1992).

Central America is an important biogeographic region; it constitutes a bridge (since Pliocene/Pleistocene age) between North and South America (Cox and Moore 1993). The region shows a mixture of species (De Ridder and Segers 1992); nevertheless, the overall influence of the neartic fauna is weak (Proalides tentaculatus, Keratella taurocephala, Lepadella triba and L. whitfordi) (De Ridder and Segers 1992). A good number of taxa have clear affinities with that of South America and the lowlands of the east coast limit their distributional patterns. This fauna is formed mainly by lecanids, lepadelids and tricocercids. The cluster analyses confirmed this statement. We found a major group (letter "A" in dendrogram, Fig. 12) formed by the Southeast Mexico, Yucatan Peninsula, Belize and Guatemala. As we stated, here we found the majority of rotifer species with South American affinity, emphasizing the transitional nature of this region between the Nearctics and Neotropics. North of Mexico has more affinity with the Nearctic fauna, with species as Keratella paludosa (Lucks), Itura chamadis Harring and Myers, Ascomorphella volvocicola (Plate) and Synchaeta tremula (O.F. Müller) (García-Morales 2001), and the Pacific coastal slope denote influence of species more tolerant to salinity. The "A" group also shows clear differences between both Mexican southern regions, for example, in Yucatan Peninsula there are more taxa related to alkaline waters (García-Morales and Elías-Gutiérrez 2004), than in the rest of the Southeast. Belize and

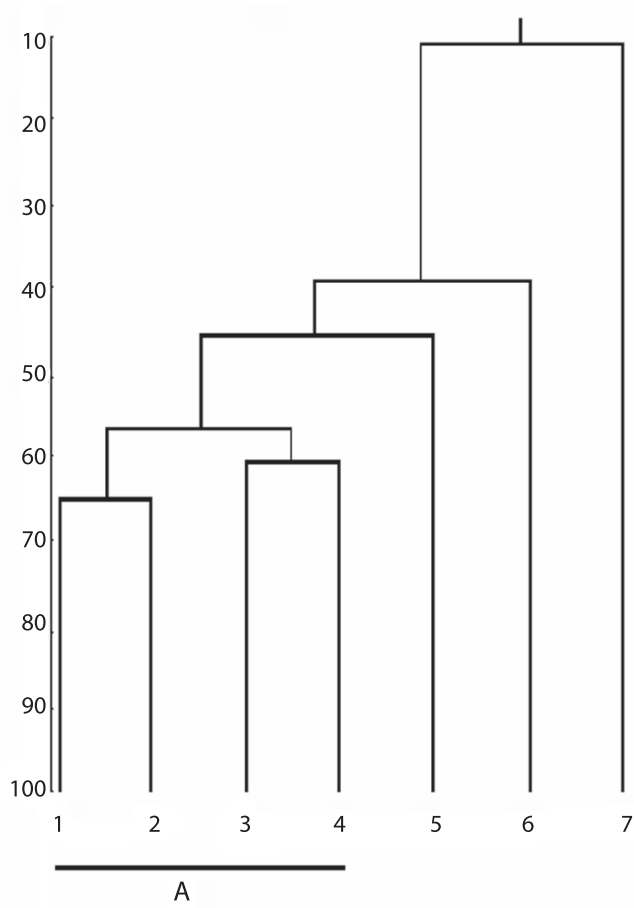

Fig. 12. Cluster analyses of the rotifers in Belize, Guatemala and adjacent Mexico. 1. Yucatan Peninsula; 2. Southeast Mexico; 3. Belize; 4. Guatemala; 5. Mexican Central Plateau; 6. North 7. Pacific slope. 
Guatemala form other sub-group, but with some differences: as seen in Table 1, a high number of taxa represented in Belize (37 species) are not present in Guatemala, and vice versa 16 species are only found in the latter. Nevertheless, the whole community makes both countries to form a cluster, separated from the south of Mexico. Regardless of the few collecting localities in both countries (11 in Guatemala and 18 in Belize), the rotifers appear to show a peculiar assemblage related to particular environments across this transitional zone that should be confirmed with further studies.

Our results and the analysis of other records suggest that the tropical forest stretching from the Amazon River basin to Central America and Southeastern Mexico is the route by which the South American fauna penetrated northwards (Cox and Moore 1993). This seems to be true for rotifer fauna, as well as other groups of aquatic invertebrates as cladocerans (ElíasGutiérrez et al. 2001, 2006), and few calanoid copepods as Prionodiaptomus colombiensis Thiébaud (Suárez-Morales et al. 2005).

Indeed, particular environments from Guatemala (as intermittent rivers, and sinkholes in Alta Verapaz) and Belize (the Mayan mountains, and many cave-related systems) deserve more intensive sampling in different seasons of the year to uncover more details about their peculiar microfauna.

\section{ACKNOWLEDGMENTS}

C. Quintal Lizama and A. Kotov participated in the collection of samples. Hendrik Segers, University of Ghent, kindly confirmed the identification of all species and assisted us with sample revision. E. Suárez-Morales made useful comments to the original manuscript. This work was part of the results in the graduate program of the first author, supported by CONACYT grant at El Colegio de la Frontera Sur, Chetumal Unit. Part of this study was supported with CONACYT-SEMARNATCONABIO Grant (Numbers C01-2002 and
AS019) for the study of the zooplankton in southeast Mexico.

\section{RESUMEN}

El análisis de muestras procedentes del norte de Guatemala y centro-sur de Belice, recolectadas en marzo de 2000 y junio de 2001, dio como resultado la presencia de 119 especies. Se presenta una breve descripción de diez taxones seleccionados con base en sus distribuciones restringidas en ciertos ámbitos de América y el viejo continente: Euchlanis semicarinata, Lepadella apsicora, L. cryphaea, Lecane curvicornis f. lofuana, L. whitfordi, Monommata maculata, Scaridium bostjani, Trichocerca elongata $f$. braziliensis, y T. hollaerti. Por primera vez se informa Lepadella rhomboidula en el continente americano. Las especies registradas incluyen $71 \%$ con distribución cosmopolita y $6 \%$ tropicopolitas; $4.2 \%$ se encuentran restringidas a los subtrópicos. La máxima y mínima diversidad de especies en Guatemala correspondió al lago Petén-Itza (con 53 taxones) y al estanque Raxruja (con tres). El estanque La Democracia (con 49 taxones) y el Blue Hole (con seis) fueron máximo y mínimo en Belice. Del total encontrado, 47 especies se registran por primera vez en Centroamérica. Una comparación entre la fauna de rotíferos de estos dos países y México refleja una similitud; sin embargo, también se aprecian ciertas diferencias que permiten establecer un gradiente que va de la región neotropical hacia la neártica.

Palabras clave: rotífero, taxonomía, diversidad, distribución, Guatemala, Belice.

\section{REFERENCES}

Archibold, O.W. 1995. Ecology of world vegetation. Chapman \& Hall, London, England. 510 p.

Collado, C., C.H. Fernando \& D. Sephton. 1984. The freshwater zooplankton of Central America and the Caribbean. Hydrobiologia 113: 105-119.

Cox, C.B. \& P.D. Moore. 1993. Biogeography. An ecological and evolutionary approach. Blackwell, London, England. 326 p.

De Paggi, S.J. \& W. Koste. 1995. Additions to the checklist of rotifers of the Superorder Monogononta recorded from Neotropis. Int. Rev. Ges. Hydrobiol. 80: 133140 .

De Ridder, M. \& H. Segers. 1992. Monogonont Rotifera recorded in the world literature (except Africa) from 
1960-1992. Studied document Van het K.B.I.N. 88. I'Institut Royal des Sciences Naturelles de Belgique, Brussels, Belgium. 481 p.

De Smet, W.H. \& R. Pourriot. 1997. Rotifera: The Dicranophoridae and the Ituridae. Guides to the identification of the microinvertebrates of the continental waters of the world. SPB, The Hague, Netherlands. $344 \mathrm{p}$.

Elías-Gutiérrez, M., N.N. Smirnov, E. Suárez-Morales \& N. Dimas-Flores. 2001. New and little known cladocerans (Crustacea: Anomopoda) from southeastern Mexico. Hydrobiologia 442: 41-54.

Elías-Gutiérrez, M., A.A. Kotov \& T. Garfias-Espejo. 2006. Cladocera (Crustacea: Ctenopoda, Anomopoda) from southern Mexico, Belize and northern Guatemala, with some biogeographical notes. Zootaxa 1119: $1-27$.

García-Morales, A. 2001. Distribución y riqueza de la fauna de rotíferos en el sureste de México, y algunas zonas de Guatemala y Belice. Tesis de Maestría, El Colegio de la Frontera Sur, Chetumal, Mexico. 74 p.

García-Morales, A. \& M. Elías-Gutiérrez. 2004. Rotifera from southeastern Mexico, new records and comments on zoogeography. An. Inst. Biol. 75: 99-120.

Harring, H.K. 1914. Report on Rotatoria from Panama with descriptions of new species. Proc. U. St. Nat. Mus. 47: $525-564$

Koste, W. 1978. Rotatoria. Die Rädertiere Mitteleuropas. Ein Bestimmungswerk, begründet von Max. Vol 2 Tafelband. Voigt Überordnung Monogononta, Berlin, Germany. 673 p.

Koste, W. \& J.S. De Paggi. 1982. Rotifera of the Superorder Monogononta recorded from Neotropis. Gewass. Abwass. 68/69: 71-102.

Koste, W. \& R.J. Shiel. 1989. Rotifera from Australian Inland Waters IV. Colurellidae (Rotifera, Monogononta). Trans. R. Soc. S. Aust. 113: 119-143.

Koste, W. \& K. Böttger. 1992. Rotatorien aus Gewässern Ecuadors II. Amazoniana 12: 263-303.

Kutikova, L.A. \& M. Silva-Briano. 1994. Keratella mexicana sp. nov., a new planktonic rotifer from Aguascalientes, Mexico. Hydrobiologia 310: 119-122.

Legendre, P. \& L. Legendre. 2000. Numerical Ecology. Elsevier, Amsterdam, Holland. 853 p.
Myers, F.J. 1934. The distribution of Rotifera on Mount Desert Island. Part VI. New Brachionidae of the genus Lepadella. Am. Museum Novitates 760: 1-10.

Nogrady, T. \& H. Segers. 2004. Asplachnidae, Gastropodidae, Lindiidae, Microcodidae, Synchaetidae, Trochosphaeridae and Filinia. Guides to the identification of the microinvertebrates of the continental waters of the world. Backhuys, Leiden, Netherlands. 264 p.

Nogrady, T., R. Pourriot \& H. Segers. 1995. Rotifera: The Notommatidae and the Scaridiidae. Guides to the identification of the microinvertebrates of the continental waters of the world. SPB, The Hague, Netherlands. 248 p.

Paggi, J.C. 1989. Rotíferos de algunas provincias del Noroeste argentino. Rev. Hydrobiol. Trop. 22: 223 238.

Pourriot, R. 1996. Rotifers from Petit Saut reservoir (French Guyana), with the description of a new taxon. Hydrobiologia 331: 43-52.

Rico-Martínez, R. \& M. Silva-Briano. 1993. Contribution to the knowledge of the Rotifera of Mexico. Hydrobiologia: 467-474.

Rico-Martínez, R., M. Silva-Briano, A. Adabache-Ortíz \& G. Domínguez-Cortinas. 2003. An updated list of rotifers from Lake Chapala, Mexico. Sci. Nat. 6: 23-32.

Sarma, S.S.S. 1999. Checklist of rotifers (Rotifera) from Mexico. Environ. Ecol. 17: 978-983.

Sarma, S.S.S. \& M. Elías-Gutiérrez. 1997. Taxonomic studies of freshwater rotifers (Rotifera) from Mexico. Pol. Arch. Hydrobiol. 44: 341-357.

Sarma, S.S.S. \& M. Elías-Gutiérrez. 1998. Rotifer diversity in a central Mexican pond. Hydrobiologia 387: 47-54.

Sarma, S.S.S. \& M. Elías-Gutiérrez. 1999a. A survey on the rotifer (Rotifera) fauna of the Yucatan Peninsula (Mexico). Rev. Biol. Trop. 47: 191-200.

Sarma, S.S.S. \& M. Elías-Gutiérrez. 1999b. Rotifers (Rotifera) from four natural water bodies of Central Mexico. Limnologica 29: 475-483.

Sarma, S.S.S. \& M. Elías-Gutiérrez. 2000. Rotifers from Mexico: New records in high altitude ponds. Southwest. Nat. 45: 366-373. 
Sarma, S.S.S. \& S. Nandini. 2002. Comparative life table demography and population growth of Brachionus macracanthus Daday, 1905 and Platyias quadricornis Ehrenberg, 1832 (Rotifera, Brachionidae) in relation to algal (Chlorella vulgaris) food density. Acta Hydroch. Hydrob. 30: 128-140.

Sarma, S.S.S., M. Elías-Gutiérrez \& C. Serranía-Soto. 1996. Rotifers from high altitude crater-lakes at Nevado de Toluca Volcano, Mexico. Hidrobiologica 6: 33-38.

Sarma, S.S.S., S. Nandini, P. Ramírez-García \& J. CortésMuñoz. 2000. New records of brackish water Rotifera and Cladocera from Mexico. Hidrobiológica 10: 121-124.

Segers, H. 1995. Zoogeography of littoral Rotifera, with special reference to the Lecanidae. Part II. Morphology and Taxonomy of Lecane. Universiteit Gent Fakulteit van de Wetenschappen. SPB, The Hague, Netherlands. 226 p.

Segers, H. 1997. Some Rotifera from the collection of the Academy of Natural Sciences of Philadelphia, including new species and new records. P. Acad. Nat. Sci. Phila. 148: 147-156.

Segers, H. \& S.S.S. Sarma. 1993. Notes on some new or little known Rotifera from Brazil. Rev. Hydrobiol. Trop. 26: 175-185.

Segers, H., N.L. Ferrufino \& L. De Meester. 1998. Diversity and zoogeography of Rotifera (Monogononta) in a flood plain lake of the Ichilo river, Bolivia, with notes on little-know species. Int. Rev. Hydrobiol. 83: 439-448.

Silva-Briano, M. \& H. Segers. 1992. Una nueva especie del género Brachionus (Rotifera, Monogononta) del
Estado de Aguascalientes México. Rev. Hydrobiol. Trop. 25: 283-285.

Silva-Briano, M. \& A. Adabache-Ortíz. 1999. On the taxonomy and distribution of the Rotifera Karatella mexicana Kutikova \& Silva-Briano, 1995. Ann. Limnol. 35: 105-109.

Suárez-Morales, E., J.W. Reid \& M. Elías-Gutiérrez. 2005. Diversity and distributional patterns of neotropical freshwater copepods (Calanoida: Diaptomidae). Int. Rev. Hydrobiol. 90: 71-83.

Uicab-Sabido, R.A. 2001. Influencia del hábitat sobre las poblaciones de rotíferos del cenote X'lakah, Yucatán. Tesis de Maestría, CINVESTAV-IPN, Unidad Mérida, Mexico. 92 p.

UNAM (Universidad Nacional Autónoma de México). 1990. Atlas Nacional de México, Instituto de Geografía, Vol II. Naturaleza, Temas Geología, Tectónica, Vegetación Potencial, Hidrogeología, Clima y Biogeografía. UNAM, Mexico. 127 p.

Valdéz-Moreno, M., J. Pool-Canul \& S. Contreras-Balderas. 2005. A checklist of the freshwater ichthyofauna from El Petén and AltaVerapaz, Guatemala, with notes for its conservation and management. Zootaxa 2005: 43-60.

\section{REFERENCIAS DE INTERNET}

Jersabek, C.D., H. Segers \& P.J. Morri. 2003. An illustrated online catalogue of the Rotifera in the Academy of Natural Sciences of Philadelphia (version 1.0: 2003-April-8). The Academy of Natural Sciences, Filadelfia, EEUU. (Available on line: http://data. acnatsci.org/biodiversity_databases/rotifer.php). 